Article

\title{
Considerations when Modelling EV Battery Circularity Systems
}

\author{
Martin Kurdve ${ }^{1,2, * \mathbb{C}}$, Mats Zackrisson ${ }^{2}\left(\mathbb{D}\right.$, Mats I. Johansson ${ }^{1}$, Burcak Ebin ${ }^{3}(\mathbb{C}$ \\ and Ulrika Harlin 1 \\ 1 Division of Supply and Operations Management, Chalmers University of Technology, \\ 41296 Gothenburg, Sweden; mats.johansson@chalmers.se (M.I.J.); Ulrika.harlin@ri.se (U.H.) \\ 2 RISE—Research Institutes of Sweden, 43153 Mölndal, Sweden; mats.zackrisson@ri.se \\ 3 Division of Energy and Materials, Nuclear Chemistry and Industrial Materials Recycling Group, Chalmers \\ University of Technology, 41296 Gothenburg, Sweden; burcak@chalmers.se \\ * Correspondence: martin.kurdve@chalmers.se; Tel.: +46-317-721-000
}

Received: 1 February 2019; Accepted: 8 April 2019; Published: 15 April 2019

\begin{abstract}
The electric vehicle market is expected to grow substantially in the coming years, which puts new requirements on the end-of-life phase and on the recycling systems. To a larger extent, the environmental footprint from these vehicles is related to raw material extraction and production, and, consequently, a material- and energy-efficient $3 \mathrm{R}$ system (reuse, remanufacturing, recycling) is urgently needed. The ability to understand and model the design and development of such a system therefore becomes important. This study contributes to this by identifying factors that affect $3 \mathrm{R}$ system design and performance, relating these factors to the various actors and processes of the system and categorising them according to time from implementation to impact. The above is achieved by applying a PEST analysis (political, economic, social and technological factors), differentiating between political, economic, social and technological factors. Data were gathered from literature, by interviews and by a number of workshops in the automotive industry and the $3 \mathrm{R}$ system and observations at meetings, etc. The study confirms some previous results on how vehicle battery $3 \mathrm{R}$ systems work and adds knowledge about the influencing factors, especially the timeframes and dynamics of the system, necessary for modelling the system and the influencing factors. For practitioners, the results indicate how to use appropriate models and which factors are most relevant to them.
\end{abstract}

Keywords: electric vehicle batteries; circular economy; recycling; reuse; remanufacturing; second life; modelling

\section{Introduction}

Most large automotive companies have recently presented platforms with battery electric vehicles (EV) and hybrids and made a fast and extensive switch to such platforms, requiring future remanufacturing and recycling systems to adapt to these technologies and to be able to efficiently manage large volumes of batteries. End of life of the vehicle will become more complex than in the past with new batteries, electronics and other parts with complex material mixes [1,2].

Vehicle original equipment manufacturers (OEMs) and their supplier base in Europe (including some battery OEMs) have increasing sustainability ambitions to contribute to a transition towards a carbon-free energy base and fossil-free energy. However, there are major challenges and many interacting factors to consider to enable reduction of life cycle environmental impact, to be more competitive and resource-efficient and increase material circularity [3,4]. The endeavour towards minimal carbon footprint, cost-efficient utilisation of resources and environmental reduction push is 
the main driving force for the ongoing technology shift towards hybrid- and electric-based propulsion with integrated digital, electronic and mechanical systems.

While electric vehicles (EV) have almost no direct emissions to air during use and give an opportunity to source fossil-free energy if green electricity is used to charge the car, they may have larger environmental impacts (e.g., toxicity, eutrophication and depletion of resources, including energy) in the material extraction and production phase than extraction and production of a similar internal combustion engine (ICE) vehicle [1,5]. Minimising extraction of scarce materials such as rare earth elements (REEs) for the production of EV batteries and sourcing of green energy for production are important strategies to keep the environmental impact low [6,7]. An efficient circularity system (hereafter referred to as $3 \mathrm{R}$ system), including materials recycling, battery remanufacturing and battery reuse, either for the same function in a vehicle or possibly in a second application, where EV batteries are first efficiently reused, possibly after a repair or remanufacturing step, and then recycled, will result in the strongest sustainability effects on the whole EV life cycle [8]. Remanufacturing here refers to when a product is rebuilt to the specification of an originally manufactured product, which in the case of batteries, e.g., could include the replacement of battery modules and software upgrade. Reuse of components or modules might be part of remanufacturing, or the complete battery pack may be reused as spare part after checking the functionality. Using the battery in a second application refers to the case when the battery is not any longer used for its original purpose in vehicles. A common example of this is as for energy buffering.

Recycling, vehicle and battery industries as well as the society at large will need-and benefit from-a sustainable battery circulation system, and a considerable amount of research has been devoted to various aspects of this in recent years. Many factors affecting the performance of the $3 R$ system for EV batteries have been investigated [1]. Although some research investigates dynamics of current and future scenarios $[9,10]$, in many cases, these factors have been considered in current situation and/or specific future situations where volumes of EVs and batteries for recycling are high and stable [8,11-13]. As the market and volumes in the coming decades are expected to evolve from today's marginal share to a dominant technology, conditions will largely change over time and so will the effect of the multi-variate factors on the performance or the 3R system. In addition, the sustainability of the 3R system of EV batteries needs to be evaluated from its dynamic role in the whole life cycle of electric vehicles and across the various phases of the industry involved in production of vehicles and components.

Given the above gap in research, the aim of this paper is first to study the details in the EV battery 3R system and identify trends and factors that can affect 3R system performance (for better or worse). Then, the paper attempts to highlight effects of important factors on the system with regard to time from application to system effect, in preparation for future modelling efforts. The above aim is approached by addressing the following research questions:

(1) How are systems for EV battery circularity constituted today? (2) What are the influencing factors needed to be considered today and in the future? and (3) How long time do these factors take between implementation and impact?

The study focuses on the contribution of $3 \mathrm{R}$ of EV batteries to the sustainability of EVs and identifies important aspects for the effectiveness of the system and what aspects evolve over time mainly from a Swedish perspective. This is done by means of literature and empirical data applied in a PEST analysis, differentiating between political, economic, social and technological aspects as described in Section 3.

\section{Frame of Reference}

\subsection{Life Cycle Impact of Electric Vehicles and Batteries}

In life cycle assessment (LCA) of fossil-driven ICE vehicles, fuel utilised to drive the vehicle is a major issue. Often, the first sustainability priority of ICE vehicle design (fossil- or bio-fuelled) has been 
to make an efficient engine and to lightweight the chassis to minimise fuel use and climate impact [11]. In comparison, EVs generally have a significantly lower life cycle impact than fossil-driven ICE vehicles [14]. However, both producing and charging EVs may use either fossil- or non-fossil-generated electricity, and the electricity sources are the most important environmental factors of EVs [15]. For vehicles using non-fossil energy sources, the use-phase importance is lower, but the importance of raw material extraction, production and end-of-life phases increases. For EVs, the extraction of raw material and production of batteries is crucial $[7,16,17]$. The direct (negative) impact from end of life for lithium ion batteries is significantly lower than from material extraction and production, but the potential secondary (positive) impact from recovering resources and thus reducing the impact from extraction and production may become large. Due to the fast pace of the transition of the automotive industry towards electrification, increased knowledge about and further research on influencing factors from a system perspective are needed.

The current trend is to increase battery size and capacity to increase range, e.g,: Ford Focus Electric from $22 \mathrm{kWh}$ to $33.5 \mathrm{kWh}$ in the 2017 model (giving $177 \mathrm{~km}$ range by US EPA standards); Nissan LEAF from $30 \mathrm{kWh}$ to $40 \mathrm{kWh} 2018$ (giving $243 \mathrm{~km}$ US EPA range) and promising $60 \mathrm{kWh}$ 2019 [18] and Tesla Model S, first launched in 2012 with a $85 \mathrm{kWh}$ battery pack and now available in $75 \mathrm{kWh}$ and $100 \mathrm{kWh}$ pack versions (giving $417 \mathrm{~km}$ and $539 \mathrm{~km}$ US EPA range) [19] indicating an upper limit of range demands and battery pack size in kWh. Energy density for EV battery packs typically vary between $80-140 \mathrm{Wh} / \mathrm{kg}$ and is usually higher in larger more luxurious vehicles [20]. Thus, EV packs normally weigh between 300 and $700 \mathrm{~kg}$. Since weight affects electricity consumption and thus range, there is a strong incentive to increase battery pack energy density which have resulted in a focus on developing high-end lithium technology, notably lithium-nickel-manganese-cobalt-oxide (NMC) cells, at the expense of lithium-iron-phosphate (LFP) cells that uses less rare metals and is safer [20]. Sourcing of the material will have an environmental impact. For EV batteries the casing, cooling and battery management system (BMS) can be half of the battery weight [17]. For example, virgin aluminium casing has a significantly large climate effect, in the same order of size as $\mathrm{Co}$, Ni or $\mathrm{Cu}$ use in an EV battery pack, while, if recycled aluminium is used, the effect will be reduced by $80 \%$ [7]. With steel casing, although the impact per $\mathrm{kg}$ is lower, the weight is higher, and it is equally important to use recycled rather than virgin grade material. Mixed material casings, e.g., aluminium and fibre-reinforced plastic may be the most advantageous from a cooling and lightweight perspective, which is important in the use phase, but it may be difficult to recycle efficiently [11]. From a vehicle life-cycle aspect, the role of the collection and 3R system should be to reduce the need of virgin material in the extraction and production phase.

\subsection{The Battery Role in the Electric Vehicle}

In traditional ICE driven vehicles, the battery is part of an auxiliary system and usually lead-based with the anode of lead dioxide and the cathode made of lead and an electrolyte containing sulphuric acid. It is a relatively cheap part compared with driveline parts but considered a hazardous component based on the risk of accidents (e.g., hydrogen gas explosions and corrosive burns on humans) and environmental damage if not properly handled.

In new EVs, the battery is usually lithium-ion (Li-ion)-based since it is lighter, can contain more energy and has a longer life than traditional lead-based batteries. The cathode typically contains lithium metal oxide (often including cobalt) or lithium iron phospate while the anode usually is a mix of graphite, and electrolytes are typically organic [21]. Several of the elements used are usually rare earth elements (REEs) or otherwise scarce, which is also the case for other EV parts [22]. The development in the field is rapid (for example in low-cobalt or cobalt-free chemistries), and new technologies are industrialised continuously [21]. The existing large-scale producers are few, but the increase of new production capacity is rapid.

A newer EV battery is powerful and is one of the most important parts in the driveline of the vehicle [23]. For EVs, batteries are one of the most expensive parts of the vehicle [15] and therefore 
from a dismantler perspective the most valuable part to recover/rescue into reuse, reconditioning or recycling. Both old and new battery technologies involve risks by overcharging batteries, which in severe cases may mean explosion, fires (in battery or charger) or damages to the battery. Batteries may also suffer from depletion by undercharging and capacity loss [24,25]. The battery pack should be placed low and safe from mechanical stress, and it needs cooling [26]. For Li-ion batteries several risks to personnel in the 3R-system connected to charging, handling and dismantling are lower than for old lead batteries but new batteries may be more complex to handle and check status on $[25,26]$. In the recycling system, Li-ion batteries may be difficult to handle; minimising safety risks is an important issue in the collection and the $3 \mathrm{R}$ system.

\subsection{The 3R System for Vehicle Industry}

The vehicle, machine and transport equipment industry in Sweden with several global vehicle OEMs (e.g., Volvo Group, Scania and Volvo Cars) has important actors for the automotive industry including some of Sweden's largest companies [27]. They produce about a quarter of Sweden's manufacturing production value [28] and $15-20 \%$ of the world's production of heavy vehicle driveline parts and include almost 1000 suppliers with more than 80,000 employees [29].

The automotive industry has long been a forerunner in reuse and material recycling, and a system for reuse and remanufacturing of parts and scrapping for recycling of steel has been in place for decades [11]. In addition, scarce materials used in, e.g., catalysts have a high reuse/recycling rate, often with a deposit-refund system. Lead batteries are recycled to a high degree partly due to legal requirements, economic incentives, social standards and a mature recycling technology. Recently, the legal demands on recycling efficiency of this system have been raised and the End of Life Vehicles Directive from the European Union requires a minimum of $85 \%$ material recycling or reuse. At the same time, trends towards lighter materials, more electronics and-in the last couple of years-electric and hybrid drivelines pose challenges to the existing system.

There are drives to strengthen producers' responsibility for end-of-life vehicles (ELV) [12] and end-of-life batteries in, e.g., EU Directive 2000/53/EC and Battery Directive 2006/66/EC. The OEMs are thus required to take more control over the $3 \mathrm{R}$ system. This is in some contrast to general free trading of spare parts according to EU law [30]. Technically, EV batteries can be reused in another car of the same model just as any other used part if the workshop can measure the status of the battery. Some business models imply that the batteries are still owned by the OEM or otherwise keep a strong link to the OEM. Recent development has included second life or second use in another energy storage solution than a vehicle [8]. In this paper, we will refer to continued use (reuse) when a battery is installed in another vehicle, while second life means repurposing in a use in a second application in accordance with [1]. It should also be noted that the End of Life Vehicles Directive does not contain any economic incentives, in contrast to EU regulation 443/2009 [31] currently driving the electrification of the European automotive sector by heavy fines for OEMs exceeding $95 \mathrm{~g} \mathrm{CO}_{2} / \mathrm{km}$ fleet average tailpipe emissions by 2021.

\section{Materials and Methods}

The data gathering included workshops and interviews with vehicle manufacturers (focusing on driveline development and sales), driveline suppliers, EV battery suppliers and recyclers, as well as participation in meetings and conferences. The empirics were gathered in three clusters: (A) overall description of the EV system, (B) current state of the EV battery 3R-system and, (C) future trends, see Table 1.

A. Description the overall electrical vehicle system and general impact factors, RED-First, four semi-structured interviews were performed together with a workshop (with 30 participants from industry and academia) on future Swedish driveline development, in order to describe the overall electric vehicle system and general impact factors on the system. 
B. Current state and technical development of Li battery recycling-Additionally, empirical data were gathered in a workshop on recycling of lithium-ion batteries (arranged by Chalmers Competence Centre for Recycling, Gothenburg, 18 January 2018) with participants from both industry and academia. This second workshop focused on the current state and technical development of Li-battery recycling. The above events were then supplemented by seven semi-structured interviews with vehicle and battery producers (sales) and two interviews with recycling system developers.

C. Future trends and RED-In cooperation with the research project TransMission, a development meeting on the ongoing transition of the driveline industry took place (arranged by TransMission, Gothenburg, 6 September 2018), and a third workshop (arranged by TransMission Industry Insights, Eskilstuna) on foresight [32,33] regarding the driveline industry was held 19 September 2018. To catch the most recent research and development, the authors also made observations at three conferences (i) Circular Materials Conference, Gothenburg, 7-8 March 2018; (ii) Conference on Circular Economy of Batteries: Production and Recycling, Gothenburg, 24-26 September 2018; (iii) Going Green-CARE INNOVATION 2018, Vienna, 26-29 November 2018) and research network meetings on electrification (Chalmers) and in the EU funded regional project CAR.

Table 1. Empirical data collection.

\begin{tabular}{|c|c|c|}
\hline Area & Type of Data & Empirics \\
\hline $\begin{array}{l}\text { A. Overall description of } \\
\text { electrical vehicle system and } \\
\text { general impact factors }\end{array}$ & $\begin{array}{c}\text { Interviews } \\
\text { Workshops \& observations }\end{array}$ & $\begin{array}{l}4 \text { semi-structured interviews } \\
\text { Workshop 1. "TransMission" ( } 30 \text { participants from industry and } \\
\text { academy working with development and research of driveline } \\
\text { and production development in mid-Sweden) }\end{array}$ \\
\hline $\begin{array}{l}\text { B. Current state and technical } \\
\text { development of } \mathrm{Li} \\
\text { battery recycling }\end{array}$ & $\begin{array}{l}\text { Workshops \& observations } \\
\text { Interviews }\end{array}$ & $\begin{array}{c}\text { Workshop 2. "Li-ion scarcity and recycling" (ca } 20 \text { external } \\
\text { participants from battery and recycling industry and academy) } \\
7 \text { semi-structured interviews (vehicle and battery } \\
\text { producers/salespersonell), } 2 \text { open interviews (recycling } \\
\text { system developers) }\end{array}$ \\
\hline C. Future trends and R\&D & $\begin{array}{c}\text { Conference discussion \& } \\
\text { observationss }\end{array}$ & $\begin{array}{c}\text { Workshop 3. Fore sight-TRM (13 participants from driveline } \\
\text { industry/production system developers)TransMission } \\
\text { development meeting (8 experts in driveline } \\
\text { industry development) } \\
3 \text { conferences: Circular material Conference 2018,Circular } \\
\text { Economy of Batteries: Production and Recycling 2018, } \\
\text { Going Green-Care Innovation } 2018\end{array}$ \\
\hline
\end{tabular}

The literature studied was found by structured and semi-structured means. The background includes literature on sustainable vehicle systems and LCA for EVs. In addition, structured literature searches were performed, using keywords such as "recycling", "battery" and "electric vehicles". Additional research papers were also found by searching conference contributors' papers. Grey literature was used mainly regarding laws and political intentions, mainly from the European Commission and Swedish government sources. In addition, various news and popular science sources of information, newsletters, newspaper articles, social media articles and company websites were used for statements on current system and future plans. The current and future 3R system constitution was mapped in Section 4.1 using interviews, workshops and literature. Input from the Swedish EV market and 3R system data, statistics and authority projections for the future were used to exemplify the nature and dynamics of the system in Section 4.3.

The analysis of data on influencing factors was inspired by [34] structuring the empirical data and literature findings in the form of a PEST analysis in Section 4.2. This method is suitable for business macro-level investigation regarding political, economic, social and technological factors to determine expectations and positive and negative impacts of these [35]. To get a better understanding of the dynamic development of the system, the PEST analysis output, categorizing aspects in political, economic, social, and technological factors was further analysed to identify where the factors act in the system, what actors are affected and how long time it takes before the change of a factor actually 
affects the recycling system (see Appendix A). The effects on some of the most important factors on the internal design factors were explained.

Finally, the results of the analyses above were further used to discuss how different actors may model various aspects of the system, including some examples using data from the Swedish EV market and 3R system. Although the empirical sources were mainly Swedish and European, the automotive industry is international, and with exception of national and European regulations, most aspects are also applicable in an international context.

\section{Results}

\subsection{Current and Expected 3R Systems}

There is a significant vehicle aftermarket that includes reused and remanufactured parts and recycling of main materials. The system for dismantling vehicles is similar in the USA, Japan and Europe although more profit-driven in the USA and more regulatory-driven in Europe and Japan [11]. Regarding the reuse and recycling of batteries from current vehicles, the system can be depicted as in Figure 1a. The main flow after vehicle end user is via dismantler to recycling, although some reuse occurs. Secondary applications are currently mainly fed by new spare battery production. With more valuable and powerful batteries, the business case of battery repair/remanufacturing as well as repurposing to second life may become profitable, and consequently a future system description must include these steps as presented in Figure 1b. We also get separate production of battery modules and battery packs (where cooling, control units and cover are added to cells/modules). There are large potentials for cost reduction from a service life cost perspective related to rest-of-pack (not related to the cell or cell chemistry); the energy consumption to drive the vehicle and the weight cost of pack account for between 45 and $61 \%$ of common EV battery packs [15]. Thus, vehicle OEMs now strive to integrate battery pack design and assembly in their core competence. Some potential business conflicts may relate to whether battery OEMs have overcapacity leading to competition between new and reused or remanufactured batteries. From a sustainability perspective, reuse is generally more efficient than remanufacturing and parts reuse, which is more efficient than recycling. In this research, the assumption is that 2 nd application use is as good as use in vehicles.

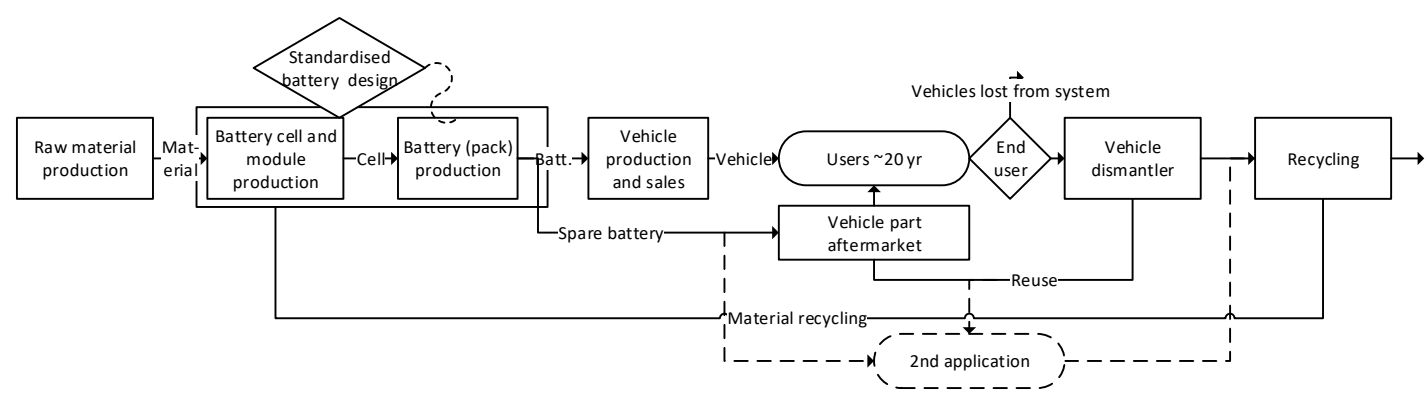

(a)

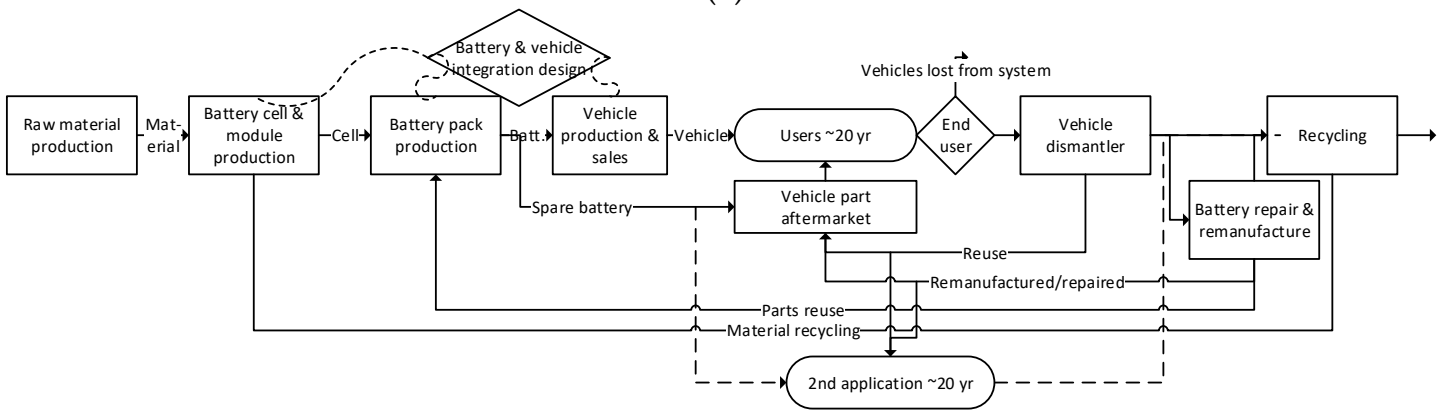

(b)

Figure 1. The 3R system for vehicle batteries: (a) current system with auxiliary battery (for lead batteries); (b) future system with electrical vehicle power batteries (Li-ion). 
Only around half of the number of unregistered cars actually enter the end-of-life vehicle system in the EU (2014); 10\% are registered exports outside the EU and the rest have an unregistered whereabouts [36,37]. In Sweden, the loss from the system is lower than the EU average. Reported ELVs are between 3.5 and $4 \%$ of the existing stock [37].

In addition, we will have material losses due to inefficiencies in all operations in the system. For general metal recycling operations, the efficiency is at best above $50 \%$ for only 18 out of 62 used metals and $<1 \%$ for 36 metals [38]. In Li-ion batteries, the most valuable materials are $\mathrm{Co}, \mathrm{Li}, \mathrm{Ni}, \mathrm{Al}$ and $\mathrm{Cu}[20,39]$ of which Li is seldom recovered. Some scarce materials used in, e.g., catalysts have a higher recycling rate [40] supported by a deposit-refund system, and recently the legal requirements on recycling efficiency in this system have been raised. At the same time, trends towards lighter materials, more electronics and in the last couple of years electric and hybrid drivelines present challenges to the vehicle $3 R$ system having to take care of a much more heterogeneous material mix from vehicles. In the short to medium term, EV battery cells will use a lot of valuable/conflict metals like cobalt, lithium and nickel [20]. In the longer term, using less rare materials must become a necessity and then the recycling of EV batteries will be less economical and may have to rely more on other incentives, e.g., legislation and/or good-will.

One trend in the vehicle 3R system is that OEMs try to keep centralised control of vehicle use data and system information to retain producer responsibility of design, parts lifecycle, repair tools, etc. This concept means that OEMs stay in charge of how to measure the status of the battery, how to repair and disassemble it and how to decide on appropriateness for second life, etc. The business model may include that the batteries are still owned by the OEM.

An opposite trend is a more independent and distributed system where dismantlers and repair shops for cars are independent of the OEM and decide on second life of parts based on business opportunities. If OEMs in that case want the batteries back because of regulation, they need to buy them on the market.

\subsection{Influencing Factors Identified in the PEST Analysis}

The factors affecting the $3 \mathrm{R}$ system found in the empirical material or in the literature are structured according to the PEST framework, which distinguishes between political, economic, social and technological factors, Figure 2a. In addition, the actor or point in the system where factors are implemented and the actor where the factors take effect with regard to Figure $2 b$ were added in order to identify factors that act early (such as design of batteries or vehicle) or late (such as tax deduction for recycling operations). The full information from the PEST analysis can be found in Appendix 1 and a summary is given in Figure 2a. The dark-coloured factors include factors that are mainly in place, while the shaded ones are such factors that may be influential in the future. Grey factors are secondary factors to the $3 R$ system that affect the number of EVs in use. The factors affect different parts of the 3R system, which is shown in Figure $2 b$. The design phase (1) and production phase (2) are outside the 3R system, while sales of batteries and EVs with batteries (3) are considered input into the system. Users of batteries and vehicles (4) trade with repair shops and collection systems (5) which in turn — via logistics and infrastructural system-let batteries go to remanufacturing (7), recycling (8) or 2nd application (11). Remanufacturing (7) resells (9) batteries to (4) and (11); recycling (8) resells material to (2) production of new batteries. 


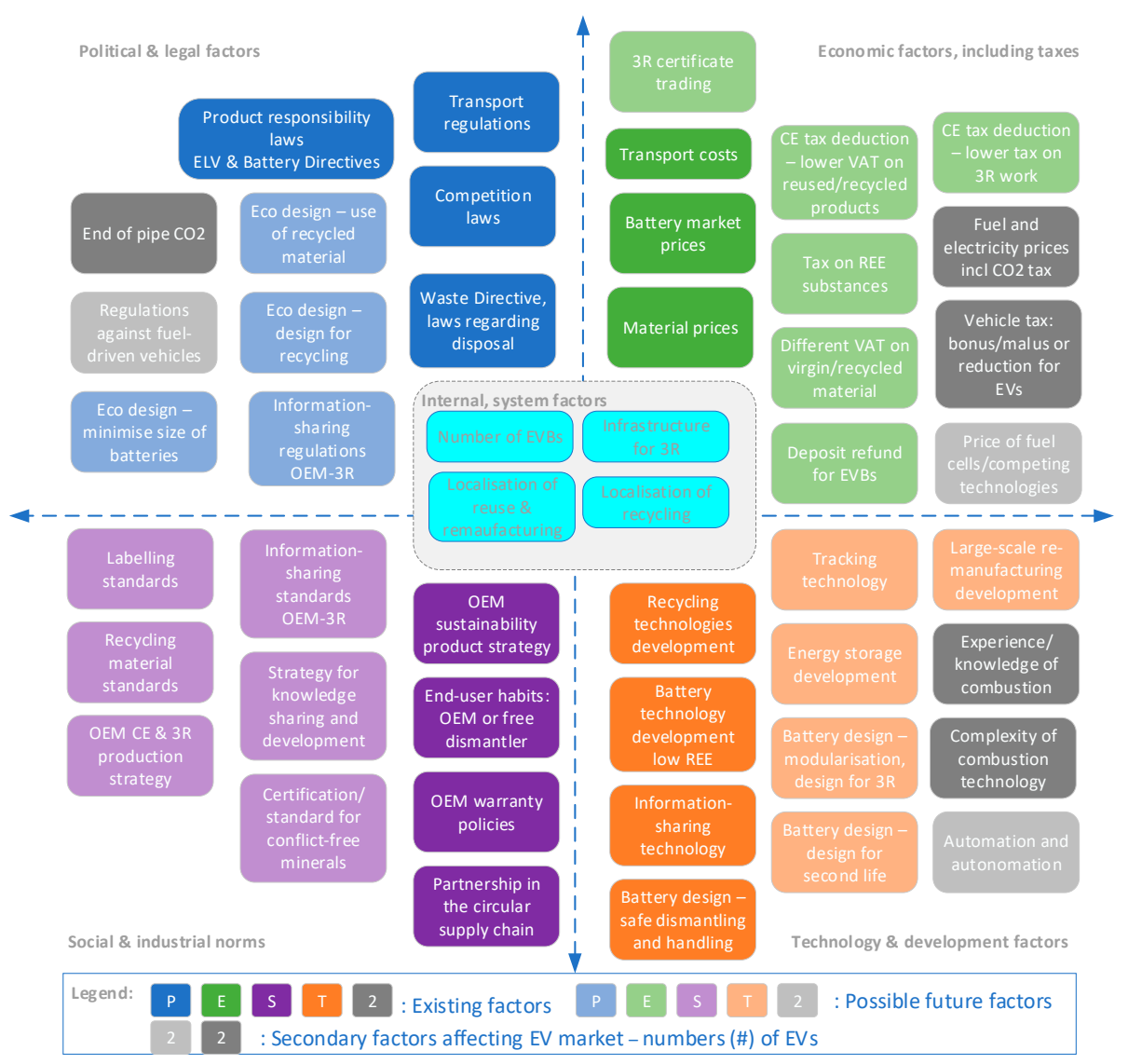

(a)

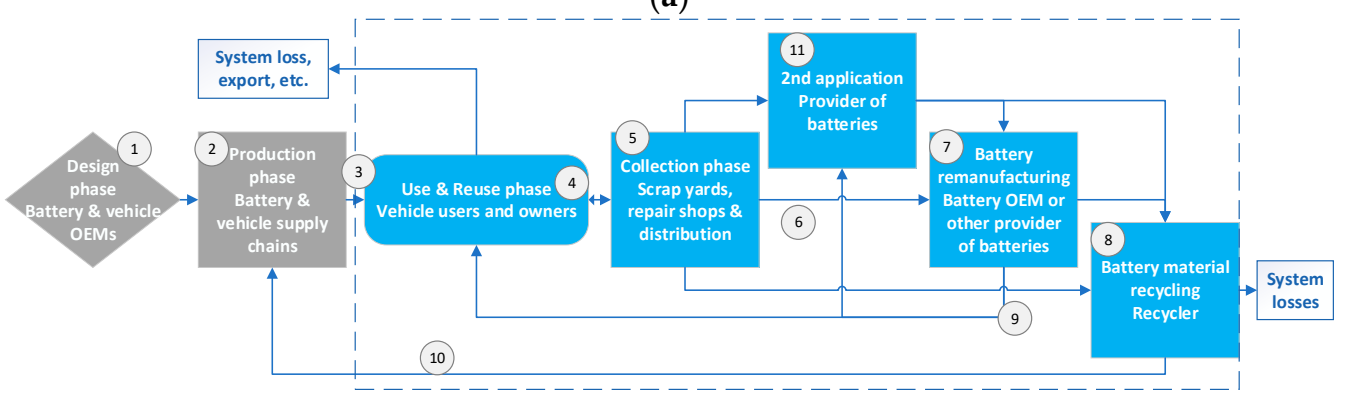

(b)

Figure 2. Summary of the results: (a) summary of the PEST analysis (political, economic, social and technological factors); (b) overview of where each of the factors influences the system. The numbers are given for each factor in Table A1 in Appendix A.

\subsubsection{Political and Legal Factors (P)}

Product responsibility regulations such as the EU's End of Life Vehicles Directive, 2000/53/EC, aiming for $85 \%$ material recovery from cars and the EU's Battery Directive, 2006/66/EC aiming for recycling of $50 \%$ by average weight of waste batteries other than lead and nickel-cadmium batteries (65\% for lead batteries) are regarded important for the 3R system [41,42] and mentioned by interviewees from vehicle and battery manufacturers. It is regulated that the collection scheme cannot add costs for private car owners leaving waste batteries. Although important, the effectiveness of the recycling rate regulation has been questioned partly because a large number of vehicles do not enter the recycling system [36], and a tighter connection between registration and end of life is proposed [41]. Substances such as lead, cadmium, mercury and chromium VI are mentioned as hazardous materials of special concern, and batteries containing these must be taken special care of. Another important factor is the competition policies of the EU (Articles 101 and 102) with rules on competition [30] 
and abuse of dominant position, ruling out exclusion of free dealers and workshops with regard to, e.g., spare parts and information connected with parts. However, there are amendments for vertical collaboration in the vehicle sector, where certification and training advantages are supposed to balance customers' drawbacks and benefits. When it comes to electronics and EV batteries, there are issues with information sharing [43] and proper dismantling that may get enforced in EU regulation in the future [44]. Policy and legislation may act as important facilitators for having information available for actors performing dismantling operations (operations efficiency and safety), and for the purpose of deciding the effective path of a dismantled battery pack. The eco-design directive mainly regulates energy efficiency for products that are not vehicles, but it is suggested in the workshops and literature to consider future resource efficiency measures [45] such as demanding use of recycled critical and valuable materials and minimised battery sizes. Eco-design requirements such as limitation of $\mathrm{CO}_{2}$ emission from vehicles have been efficient in that vehicle OEMs respond to the requirements, increasing the EV fleet, but their effect on the 3R-system for EVs is secondary. Other regulations that may increase the EV fleet mentioned in workshops are free parking and allowing bus-lane driving. An unregulated 3R system will need further open information to achieve a free market for dismantlers [46] and is expected to be efficient for reuse of high-value parts but less efficient for circulating low-value parts and recycling especially if there is a cost for recycling and disposal.

\subsubsection{Economic Factors Including Taxes (E)}

The market prices of materials, especially scarce or near scarce materials, are mentioned in the literature [47] and by OEMs as critical factors for driving the recycling system. Material cost is estimated to be over $60 \%$ of total battery cost, and other battery production costs are expected to stabilise at rather low volumes around twenty thousand battery packs per year [23]. Likewise, the battery price is a driver for reuse and remanufacturing [8]. A high price of new batteries means high potential revenue on reused or remanufactured batteries while too high prices may limit the number of EVs introduced into the system. High costs of handling and transport for used batteries are mentioned by recyclers interviewed as a possible obstacle to an efficient 3R system. Introduction of deposit refunds for recycling is an effective tool for increased circularity [48]. With high battery recycling cost a deposit refund can be an enabler for returning batteries to recycling as stated in the expert workshops and interviews. Material tax on critical elements (e.g., cobalt tax) could be effective, while trading of recycling certificates is mentioned but not perceived as effective. There are several factors mentioned as secondary economic factors affecting the number of electric vehicles sold, such as fuel and electricity prices, tax and fee deductions and carbon trading.

\subsubsection{Social and Industrial Norms (S)}

Sustainability business strategies of battery and vehicle OEMs are important drivers for a sustainable $3 \mathrm{R}$ system and companies' design and development plans. The OEMs state that their involvement in the 3R system is dependent on their business strategy. Information sharing and standardization of information and information interfaces, e.g., in the International Dismantling Information System [44], certified brand-specific systems, labelling [49], status checks and BMS control are mentioned by recyclers and in workshops as a requirement for efficient handling and selection of path into 3R system for batteries. Some vehicle OEMs point out that end-user behaviour regarding whether they leave the vehicle to certified dismantlers [12] or other types of dealers or dismantlers is crucial for efficiency and risk of losses in the system. Customer demands for certification of ethical and conflict-free products may also influence the market for recycled materials.

\subsubsection{Technology and Development Factors (T)}

Vehicle and battery OEMs state that technology development will have an impact on the 3R system for EV batteries. First, battery cell development--especially with regard to what metals and chemistry are used-will affect the material effectiveness of the system, and the rate of change will 
determine whether recycling of old batteries into new ones will become obsolete. New technology with limited use of critical elements can be crucial not only for batteries, but for all electric components [22]. Recycling technology development is both expected and needed according to interviewees in the recycling industry. Current pyrolysis technology recovers cobalt, but new technologies for chemical leaching may recover most of $\mathrm{Co}, \mathrm{Li}$ and $\mathrm{Ni}$ with high yields [39]. Having information available on battery chemistry is important to the recycling actors, especially in open systems where a multitude of manufacturers' battery packs are recycled. The battery pack design is crucial for safety issues and cost, e.g., cost of disassembly [13], in the 3R system. This relates to research and development of robotised disassembly of battery packs $[50,51]$. Battery and vehicle OEMs mention that design of cells and modules may be adapted for changing faulty cells and modules in repair and remanufacturing [25] and modularisation may provide greater safety and longer life of batteries [24]. Vehicle OEMs mention that proper status checks and possibly tracking of batteries, not yet on the market, are needed for an efficient 3R management, especially for reuse and second life. The energy storage technology development may affect both the market for primary batteries and the market for second life. Some vehicle OEMs expect that the EV technology will soon be dominant on the market with fewer complex parts and lower maintenance cost.

\subsubsection{Coupling between Perspectives and Internal 3R Factors}

Several of the PEST factors are interrelated over the quadrants. As depicted in Figure 3, some factors are dependent on others, such as "Battery design-safe dismantling and handling" is dependent on "Labelling standards" and different factors involving information sharing. Some factors like "Information sharing technology" may also be an alternative to, e.g., "Labelling standards" and may enhance "Information sharing standards". Finally, some factors like "Information sharing standards" and "Information sharing regulations" may be replacive, alternative factors since, if the industry cannot agree on a standard, policymakers may enforce regulations giving a similar result. Depending on what the aim when modelling or otherwise using the factors in analysis of the 3R-system, the crucial interrelations for the model need to be determined.

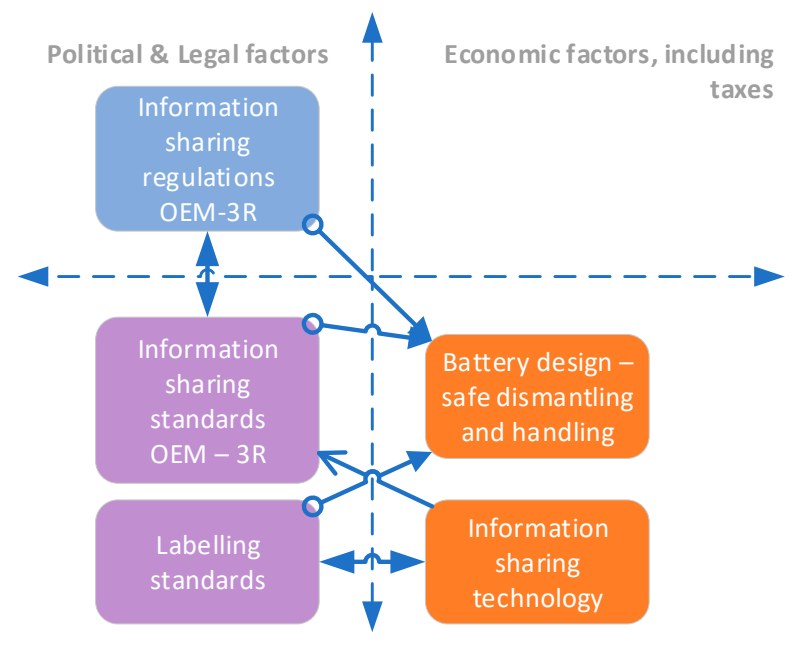

Social and industrial norms Technology \& development factors

Legend: $\mathrm{O} \longrightarrow$ : Dependent factor $\longrightarrow$ : Alternative factors $\longrightarrow$ : Enhancing factor

Figure 3. Example of interrelated factors.

In addition to the PEST factors, the study identified factors that may be seen as internal or semi-internal to the 3R system. First, the number of EV batteries in use, which relates to how many EV batteries enter the $3 R$-system and affect the infrastructure of $3 R$ in terms of number and localisation of collection points, remanufacturing and recycling facilities. The infrastructure and the relations 
between actors in the system are important, as well as the rules of conduct under which they work. Centralised or decentralised localisation of control of reuse, repair and remanufacturing will depend on the organisation of the infrastructure and the relations to, e.g., OEMs. The economics in the system will affect actor behaviour. In particular, the recycling facilities require large capital investments, and it has been proposed that recycling could be co-located with other metal industry (mine and smelters) or with cell production.

Some of the identified PEST factors will push towards a free-market infrastructure approach where all actors will act for the benefit of an efficient system. Such an ideal system works if the resource benefits are equally distributed among actors and no actor profits from overproduction. Responsibilities of decisions and operations will be distributed among the actors. This system requires substantial standardisation and open (accessible) information.

A second approach is a regulated system where essentially battery or vehicle OEMs-whoever puts the product on the market - control the flow of used batteries and take on the responsibility to make the flow as efficient as possible. This is likewise an idealised situation that demands that actors follow rules and do not cheat for their own benefit. Closed information and OEM-reliant operations mean that large volumes are required for high efficiency of such a system.

All in all, we can conclude that the most important factor affecting collection and 3R system is the rolling stock of electric vehicles/the fleet size of EVs in use; thus, some indirect factors that will directly have a large impact on EV fleet and EV market have been included in the PEST analysis. In addition, the internal infrastructure of the system will be a major factor with an impact on the efficiency of the $3 R$ system. However, these factors will be heavily influenced at different stages by all the other PEST factors.

\subsection{Exemplifying the Time Effects in the Case of Sweden}

Some of the factors will take a long time after implementation before having an effect in the system. Although battery design will have a strong influence on the system, it will take long before the effect is seen in the $3 \mathrm{R}$ system. Other factors act immediately on the system. It is expected that the share of EVs in the vehicle stock will increase and eventually develop in an s-shaped curve. What we cannot know exactly is how fast the growth will be or at what level it will stabilise. In addition, some experts (at TransMission development meeting and Circular economy conference) claim that the total number of vehicles in Europe may be reduced due to car sharing initiatives and development of other transport modes. Other experts think that development of autonomous vehicles will increase the number of vehicles [52] and it will definitely increase the number and weight of electronics per vehicle (TransMission development meeting).

Policies on a battery recycling rate of $50 \%$ or higher will be effectuated into the recycling system immediately. However, at the moment, volumes are low and the policies might be expensive to implement, but, with gradually higher volumes, it may be possible to lower recycling cost per battery. One problem may be that the high initial cost reduces the implementation rate.

Design decisions made for the next car model will affect cars in production only after several years. Then, the model will be produced for up to seven years. For heavy vehicles, the time is longer. The warranty period for the battery is typically eight years and the average lifespan before end-of-life for EVs may be 8-24 years or more. This means we can expect start ramp-up of large-scale reuse and remanufacturing for a battery model around 10 years after design, with expected full-rate recycling around 20 years after design and then declining from 30 years after design. It is clear that reuse and second application may become technologically or marketwise obsolete during this lifespan. Time to recycling may be another 20 years added after design, if used in a second application, meaning that we need to plan the recycling up to 50 years from now.

If the latest environmental goals of Sweden for the transport sector are valid, we should reduce $\mathrm{CO}_{2}$ from the vehicle fleet by $70 \%$ between 2010 and 2030 (of which $18 \%$ was achieved until 2018) and then go down to zero by 2045 [53]. Forty per cent of the decrease is supposed to come from 
an increasing mix of biofuel into petrol and diesel. However, the available total amount is believed to be limited. The final $42 \%$ have to come from electrification of vehicles. This means that we need to have at least $42 \%$ of traffic work represented by electric vehicles by 2045. Currently, the Swedish stock of electric and hybrid vehicles is only about 4000 vehicles out of a total stock of 4.9 million vehicles. In addition, $42 \%$ would mean at least two million electric vehicles on the road. This is in line with, e.g., the Boston Consulting Group 2018 analysis [54], expecting 48\% of vehicles to be electric or hybrids by 2030 .

The battery collection capacity demand for the 3R system in Sweden can be estimated, assuming that we reach a static steady state system with no technology development and two million electric vehicles of uniform age distribution and a lifespan of 8-24 years [55]. Then, the average lifespan is 16 years and every year, $1 / 16(=6.25 \%)$ of the two million vehicles will enter the Swedish $3 \mathrm{R}$ system. To have a steady state with no losses (export), the 3R capacity demand will be the same, around 125,000 batteries per year (or around 70 batteries per work hour with day shift). If these are collected into only one plant for sorting, preparing for reuse, second life and recycling, this information may be sufficient to make an investment plan. We may even add export leakage flow and make an environmental value stream map, calculate lead-times and total number of batteries in the system, Figure 4. This results in an estimated average time of 30 years from design until a battery enters recycling (and some will take much longer).

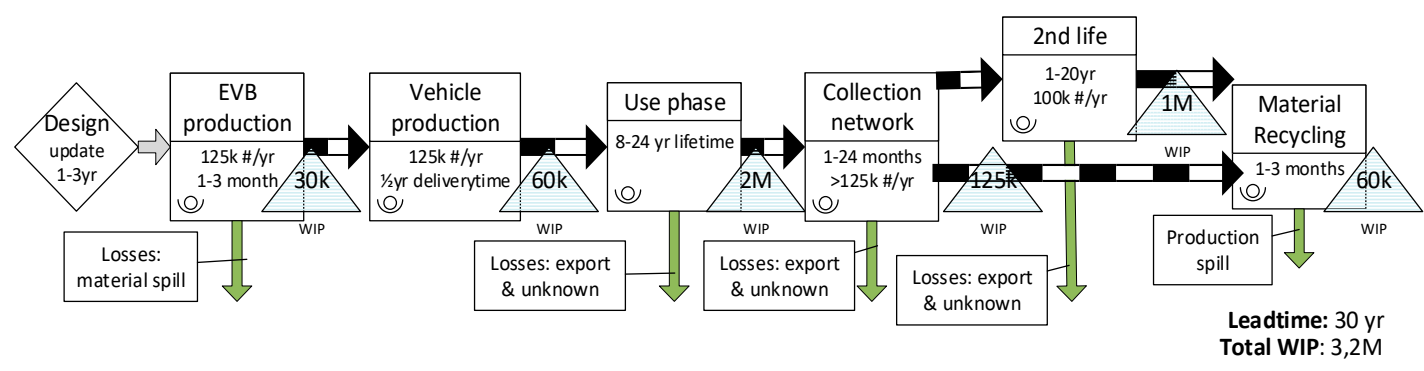

Figure 4. Value-stream map overview of the projected design to recycling, with Swedish data.

The number of registered vehicles is still increasing by an average of $1.1-1.5 \%$ yearly [56], but the vehicle industry interviewees (representing both cars and heavy vehicles) state that they expect that there will be a decrease in the number of vehicles but with the same or increasing number of kilometres driven. It is a gamble to know when and at what rate such decrease will start, but representatives of the Scandinavian trade association for suppliers to the automotive industry expect a rise of sales of vehicles for the next three to five years and then a decline starts. The timing of the decline depends on how fast an expected general economic downturn comes. In order to reach over two million electric vehicles in the Swedish fleet, over two million electric vehicles need to be sold over the next 26 years. If we expect to go quickly towards a steady state, we should aim for two million in less than 20 years, which is equivalent to $>100,000$ electric vehicles per year.

For comparison, Europe, USA and Japan have similar 3R-systems [11]. The situation is similar to Sweden in most of Europe, although the losses into "unknown whereabouts" of vehicles are larger in southern and eastern EU [36]. The P factors are mainly the same all over EU and, since the vehicle industry is fairly global, most E, S and T factors are also similar in US and Japan, but with different individual factor strengths. The time-effects are similar in a global perspective, but the share of EVs in the vehicle fleet may need to be larger in countries with less capacity for biofuel production if world-wide climate objectives are to be held.

\subsection{Discussion and Modelling Implications}

As the volume of EV batteries will radically increase in a few years, incitement of stakeholders and business cases for circularity solutions for EV batteries may increase, thus providing early adaptors to 
take competitive advantages. However, these factors need to be taken into early account in design phases, requiring a partnership collaboration in the entire life cycle of EVs.

Since some factors will take long before they affect the system and other factors act immediately, modelling has to take different paths depending on the actor or focus of interest. The output of such models may be on different levels. Some actors need to model and predict the required capacity of future recycling processes, while policymakers have to predict how different policies or incentives will affect the system, and still other actors need to predict how their own strategies and other actors' behaviour affect performance, etc. A model should always be as simple as possible but still be reliable enough to give a correct input for decisions.

Static models may fulfil the purpose if one wants to know the collection capacity demand in a static steady state system with no technology development and uniform age distribution and lifespan. Then, the average lifespan and vehicle exchange rate can provide scrapping rate and collection system capacity need as described in Section 4.4. Value-stream mapping or projected life-cycle cost calculations may be sufficient to model the system and give decision support for investments.

For dynamic systems, however, there is a need to develop statistical or simulation models to predict system behaviour. The steady-state behaviour, if achieved, should here be supplemented by models that focus on the behaviour up until the steady-state phase. One option is to perform stock and flow system dynamics simulations of the recycling system for EV batteries [9]. With EV life expectancy of 8-24 years, the 3R system for EV batteries needs to be ramped up starting around 2027 and in full capacity a few years later. System dynamics may be useful to model stocks and flows taking production capacity in mind as depicted in the simple model in Figure 5, showing the material flow. However, Figure 5 only visualises the general limitations of the system, to predict the actual behaviour of the system, several of the factors mentioned in the PEST analysis need to be brought into the model.

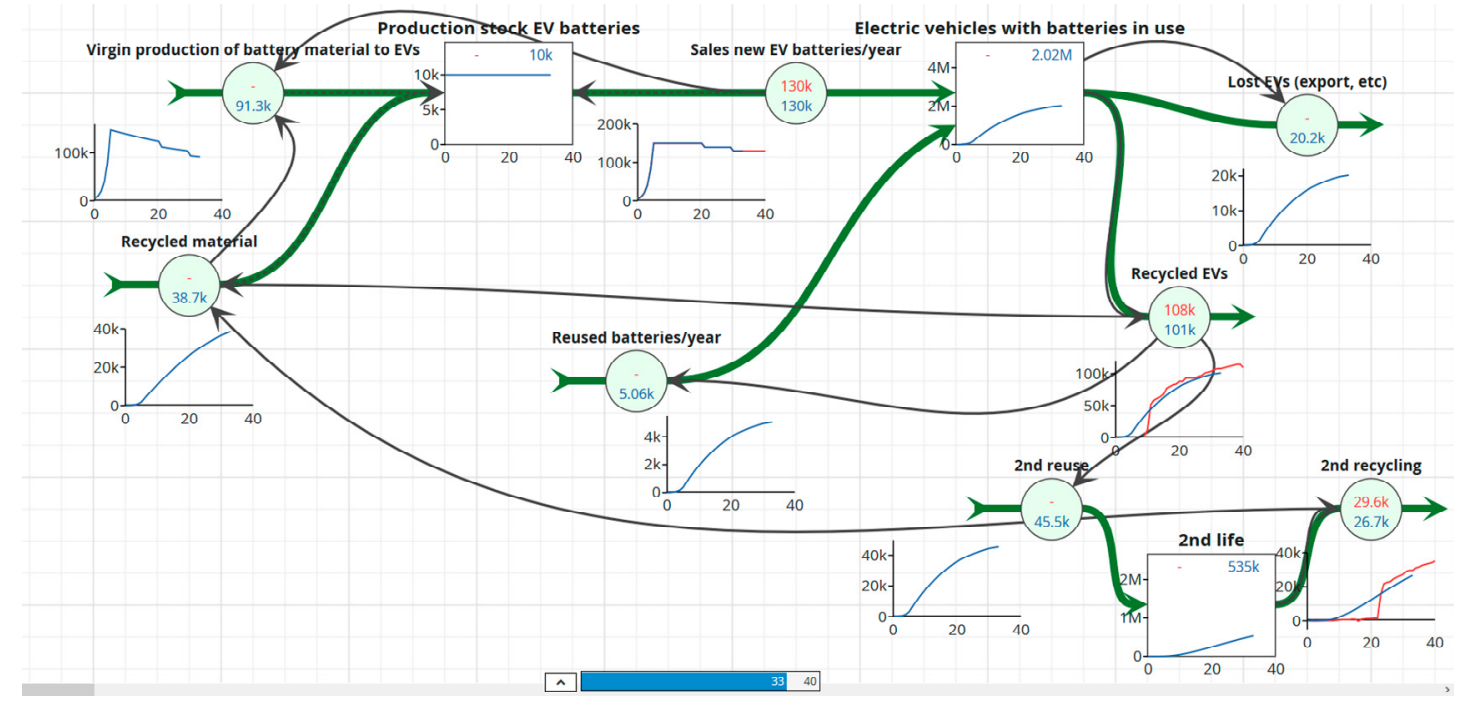

Figure 5. Example of a basic stock and flow system dynamics model with relations of stocks and flows.

In addition, actors in the system will need to determine the required capacity of different operations in the system, allocate different operations and appoint labour-in short, design the production system (PS). If such a PS model for the 3R system is studied, then the manufacturing of batteries, vehicles and the use phase of the vehicle can be seen as the supply chain of that PS. For different issues, different dynamics are interesting and a multi-scale simulation approach may be useful [57]. To this end, all relevant volumes and fluctuations need to be calculated or estimated beforehand. A simple discrete event simulation (DES) model with different production capacity and labour allocation is shown in Figure 6. Although there may be a problem with long lead times when deciding on what external 
factors-e.g., laws and economic incentives-to implement, it may be positive that several of these factors can be regarded as fixed over long periods of time when designing processes in the $3 \mathrm{R}$ system.

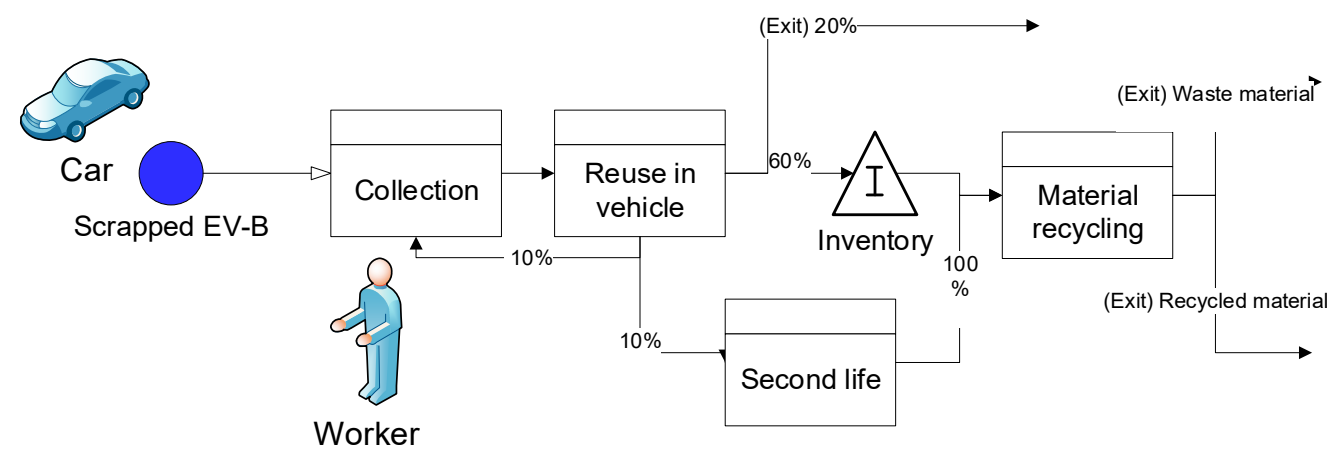

Figure 6. Example of a simple discrete event simulation model of collector capacity for different rates of reuse, recycling and second life.

For detailed simulation of, for example, semi-automatic robot cells for status check or disassembly, a dynamic simulation in 3D may be appropriate to support design and operation of such a process. In order to plan material flows, static capacity planning and VSM should be enough or-if needed-discrete event simulations may be used to study dynamic behaviour and planning of operations. Agent-based or stochastic models may be used to predict outcome of actor (e.g., end user or individual collectors) behaviours, and system dynamics can often be appropriate to model the overall supply and demand system [57].

When modelling, or using models, the following questions may be applied:

- What timeframe is the modelled system and input data valid for?

- Are all significant changing factors modelled as variables?

- Are all other factors stated and modelled as constant?

\section{Conclusions}

From vehicle life-cycle perspective, in order for the transportation sector to be in line with climate and sustainability goals of society, there is a need to have an efficient $3 R$ system. At the end of the loop, it is crucial that especially critical and valuable raw materials are recovered by recycling. Several factors having direct or strong indirect impact on the system have been identified from empirical data and the literature. The considerable time lag between interventions in the system and the time they take effect makes it difficult to predict the future due to long design time and long technical life of vehicles concurrent with a rapid technical development. Therefore, modelling future states of the $3 \mathrm{R}$ system has to take into account that some factors have different effect over time and that the system performance over time is as interesting and important as a future steady-state performance of a system, if such a state will at all exist for Li-ion batteries.

As concerns second application of used vehicle batteries-often stated as promising and effective- there is a risk that such applications are obsolete at the time when the volumes of available used EV batteries become large. Thus, there is need to build in flexibility and reconfigurability in the design of the battery. This also affects recycling, and it cannot be certain that the REEs recovered will be used in Li-ion batteries for EVs. Therefore, with estimated average 30 years between product design and material recycling, an open loop approach for recycling may be more valid.

The business relations in the system are important. Here, two approaches can be identified, (1) a free-market approach that optimises best path through market mechanisms, which would need very clear legal, economic and social incentives to ensure 3R efficiency, and (2) a producer responsibility approach in which OEMs releasing batteries on the market keep strict control and rule all paths. This latter approach is vulnerable for actors that break the rules, and, in less heavily penetrated markets, 
it may be inefficient. In real life, mixes of both these approaches will be expected. The dynamics of the system call for different types of modelling for different purposes. For modelling subparts of the system, a number of long-term factors can be treated as fixed. For holistic system analysis, system dynamics may be useful.

This study confirms to some extent results in other recent studies on how the vehicle battery $3 \mathrm{R}$ system can be developed $[1,8,42]$ and adds knowledge about the influencing factors on the system and especially the time frames and dynamics of the system necessary for modelling the system and the influencing factors. For practitioners, the results indicate how to use appropriate models and what factors are most relevant to them.

Author Contributions: Conceptualization, M.K., M.Z. and M.I.J.; Methodology, M.K.; Software, MK.; Validation, U.H., M.Z, B.E. and M.J.; Formal Analysis, M.J, U.H, M.Z, and M.K; Investigation, M.K. and M.J.; Writing-Original Draft Preparation, M.K. B.E.; Writing-Review and Editing, M.K, U.H, M.Z, M.J and B.E.; Visualization, M.K.; Project Administration, B.E.; Funding Acquisition, M.J.

Funding: This research was funded by Chalmers Area of Advanced Transport and by XPRES, Excellence in production research.

Conflicts of Interest: The authors declare no conflict of interest. The funders had no role in the design of the study; in the collection, analyses, or interpretation of data; in the writing of the manuscript, or in the decision to publish the results.

\section{Appendix A}

Table A1 includes the full result of the PEST analysis in Section 4.2. Each factor influencing the 3R-system that were found in the empirical data collection has been listed under the four quadrants (P, E, S T and Internal) with a description, a point of influence (PoI) and point of effect (PoE) - where numbers refers to Figure $2 b$, comments, and the empirical source mentioning the factor. Shaded factors are all secondary factors influencing the EV-market and thus the number of EV batteries in use. The numbers in PoI and PoE refers to:

1. Design phase

2. Production phase

3. Sales to user-Use and reuse phase

4. End of use of battery-User and reuse phase

5. Collection phase

6. 3R-system infrastructure and connections

7. Battery remanufacturing

8. Battery material recycling

9. Provision of remanufactured batteries and or reused parts

10. Provision of recycled battery material

11. Second application, non-vehicle reuse of batteries and remanufactured batteries. 
Table A1. PEST analysis (political, economic, social and technological factors).

\begin{tabular}{|c|c|c|c|c|c|}
\hline Factor & Description & Point of in-Fluence & Point of Effect & Comment & Empirics \\
\hline & P: Political and legal factors & PoI & PoE & Comment & Empirics \\
\hline Product responsibility & ELV dir. recycling targets $95 \%$ & 1 & 8 & In place-weak follow up & $\begin{array}{c}\text { OEM interviews, WS, car-sales } \\
\text { interviews }\end{array}$ \\
\hline Product responsibility & Battery dir. recycling targets $\mathbf{5 0} \%$ & 1 & 8 & In place for collected batteries & Some battery OEM \\
\hline Waste dir. disposal laws & Illegal to dispose in landfill & 8 & 8 & Seen as self evident by interviewees & Experts, some interview \\
\hline Transportation regulation & Batteries as haz. goods transportation & 6 & 6 & Dangerous goods/hazardous mtrl & Recycler \\
\hline Ecodesign-use recycled materials & Demand $\mathrm{x} \%$ recycled mtrl & 1 & 2,1 & Influences market price for Re & Suggested in WS \\
\hline Ecodesign-efficiency & Minimise battery size & 1 & 2 & So far demands on en-efficiency & Not mentioned/adressed \\
\hline Ecodesign-DfRecycling & Demand on recycling instructions etc & 1 & 8 & "Could give great effect" & Mentioned in WS\&int. \\
\hline Information sharing & Demand status and dissasembly instr. & 1 & 5 & Important according to recyclers & WS \& recycler int. \& CEB \\
\hline (EU) export regulations & export control & 1 & 4 & Since ELV dir. is not valid outside EU & Car OEM interview \\
\hline End of pipe- $-\mathrm{CO}_{2}$ & Ecodesign $\mathrm{CO}_{2} /$ fuel consumption & 1 & 2 & Secondary factor & OEM interviews \\
\hline \multirow[t]{2}{*}{ Rule out fuelled vehicles } & Regulations stopping fuelled vehicles & 3 & 3 & Buss lane, parking, etc. & News \\
\hline & E: Economic including taxes & PoI & PoE & Comment & Empirics \\
\hline Material prices & Market prices of each of (rare) material & 2 & 10 & depend on demand, & OEM interviews \\
\hline Battery market price & Price of batteries & 3 & 3 & decreasing? & Some OEM interviréws \\
\hline Transport cost & Cost to transport Haz material & 6 & 6 & High, decreasing & Recycler \\
\hline Deposit-refund systems & Refund fee at purchase-return at recycling & 3 & 5 & Defined per kWh? Time aspect? & WS/interviews \\
\hline CE tax deduction-work & Tax reduction on repair/reuse operations & 7,8 & 9,10 & Exist for e.g. bike repairs. & Not mentioned \\
\hline CE tax deduction—product & Lower VAT on Re-X products & 3 & 9,10 & Increase sales of reused batteries & mentioned in WS \\
\hline $\mathrm{CE}$ tax deduction—recycl.material & Tax on virgin or tax cut for recycled mtrl & 2 & 10 & Mining tax vs recycling tax & Recycler \\
\hline $3 R$ certificate trading & E.g. recycling certificate trading & 10 & 3 & Tried in UK, not clear success & Mentioned in WS \\
\hline Scarce material taxes & Taxes/tolls on certain products/materials & 2 & 10 & E.g. Cobolt tax & Literature \\
\hline Vehicle tax & Bonus malus on vehicle taxation & 3 & 3 & Increase EV market share & OEM interviews \\
\hline Fuel price- $-\mathrm{CO}_{2}$ cost & $\mathrm{CO}_{2}$ fee & 3 & 3 & Increase EV market share & OEM interviews \\
\hline Fuel prices-fuel & Price and taxes of fossile fuel & 3 & 3 & Increase EV market share & OEM interviews \\
\hline Fuel prices—electricity & Price and taxes of electricity & 3 & 3 & Decrease EV market share & Secondary \\
\hline \multirow[t]{2}{*}{ Price for competing tecnhnol. } & E.g. price of fuel cells & 3 & 3 & Decrease EV market share & Some OEM interviréws \\
\hline & S: Social and industrial norms & PoI & PoE & Comment & Empirics \\
\hline OEM warranty policies & OEM warranty policies and regulations & 3 & 4 & Warranty and takeback agreement & Vehicle OEM \\
\hline Business strategy-product & Corporate product strategies (economic) & 1 & 3,5 & Green product strategy- & Battery OEM \\
\hline Labelling_-standards & Labelling standards (combined Tracking?) & 3 & 5,6 & Important according to recyclers & Recycler int, WS \& CEB \\
\hline Industrial information sharing & Standard information syst. (from BMS) & 2,5 & 4,5 & Not widely used. & Recycler \\
\hline End user habits/behaviour & $\begin{array}{l}\text { Users used to going to OEM certified } \\
\text { dealer/scrapper }\end{array}$ & 4 & 5 & OEM-controlled 3R & Vehicle OEM \\
\hline End user habits/behaviour & Users used to using "free part dealers" & 4 & 5 & Free market $3 R$ & Not mentioned \\
\hline Business strategy for CE \& $3 R$ & Customers + OEM aim at $3 \mathrm{R}$ production & 2 & 9,10 & 3R awareness & Mentioned in WS \\
\hline Business strategy - partnership & $\begin{array}{l}\text { Partnership in (circular) supply chain (e.g. } \\
\text { material flow partnership) }\end{array}$ & 3 & 5,7 & Negotiate information sharing & Literature \\
\hline Business strategy—sharing innov. & Different strategies for knowledge sharing & 1 & $5,7,8$ & E.g. open innovation in SC & Literature \\
\hline Recycling material standards & Industrial standards for recycled mtrl & 8 & 10 & May increase rec. market (value) & Suggested in WS \\
\hline Conflict-free materials & $\begin{array}{l}\text { Standard or certification of } \\
\text { conflict-free/ethical demands }\end{array}$ & 9 & 10 & Raise price and or incr. recycling & Not mentioned \\
\hline
\end{tabular}


Table A1. Cont.

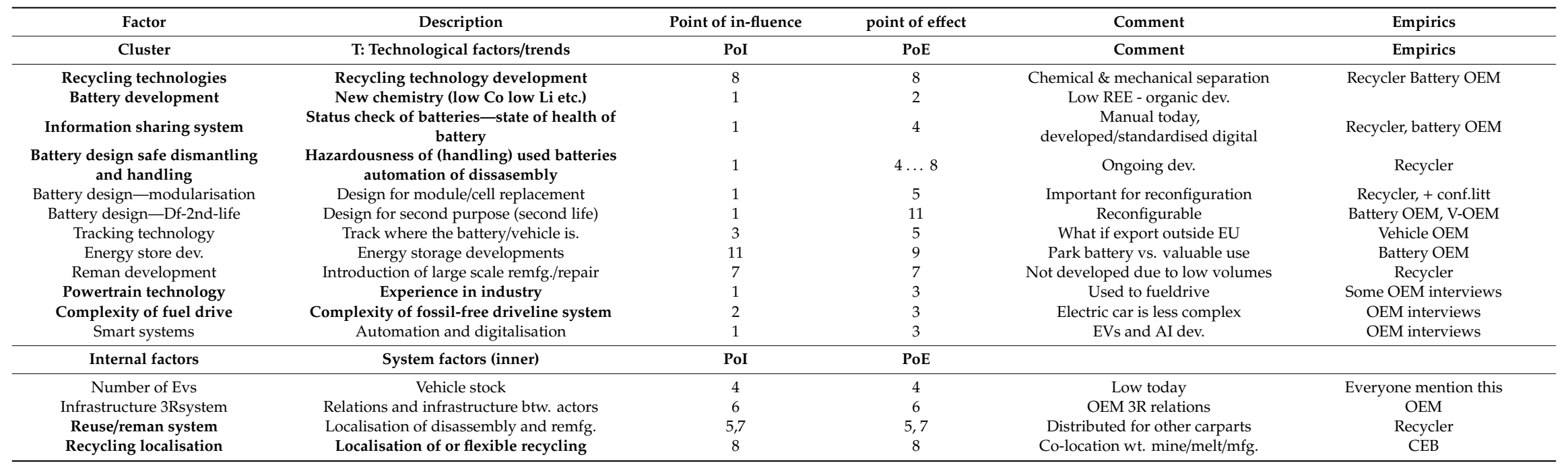




\section{References}

1. Zhang, X.; Li, L.; Fan, E.; Xue, Q.; Bian, Y.; Wu, F.; Chen, R. Toward sustainable and systematic recycling of spent rechargeable batteries. Chem. Soc. Rev. 2018, 47, 7239-7302. [CrossRef]

2. Ortego, A.; Valero, A.; Valero, A.; Iglesias, M. Downcycling in automobile recycling process: A thermodynamic assessment. Resour. Conserv. Recycl. 2018, 136, 24-32. [CrossRef]

3. Hao, H.; Qiao, Q.; Liu, Z.; Zhao, F. Impact of recycling on energy consumption and greenhouse gas emissions from electric vehicle production: The China 2025 case. Resour. Conserv. Recycl. 2017, 122, 114-125. [CrossRef]

4. Ortego, A.; Valero, A.; Valero, A.; Restrepo, E. Vehicles and Critical Raw Materials: A Sustainability Assessment Using Thermodynamic Rarity. J. Ind. Ecol. 2018, 22, 1005-1015. [CrossRef]

5. Yu, A.; Wei, Y.; Chen, W.; Peng, N.; Peng, L. Life cycle environmental impacts and carbon emissions: A case study of electric and gasoline vehicles in China. Transp. Res. Part D Transp. Environ. 2018, 65, 409-420. [CrossRef]

6. Zackrisson, M.; Avellán, L.; Orlenius, J. Life cycle assessment of lithium-ion batteries for plug-in hybrid electric vehicles-Critical issues. J. Clean. Prod. 2010, 18, 1519-1529. [CrossRef]

7. Romare, M.; Dahllöf, L. The Life Cycle Energy Consumption and Greenhouse Gas Emissions from Lithium-Ion Batteries; IVL: Stockholm, Sweden, 2017.

8. Olsson, L.; Fallahi, S.; Schnurr, M.; Diener, D.; van Loon, P. Circular Business Models for Extended EV Battery Life. Batteries 2018, 4, 57. [CrossRef]

9. Kumar, S.; Yamaoka, T. System dynamics study of the Japanese automotive industry closed loop supply chain. J. Manuf. Technol. Manag. 2007, 18, 115-138. [CrossRef]

10. Natkunarajah, N.; Scharf, M.; Scharf, P.J.P.C. Scenarios for the return of lithium-ion batteries out of electric cars for recycling. Procedia CIRP 2015, 29, 740-745. [CrossRef]

11. Kumar, V.; Sutherland, J.W. Sustainability of the automotive recycling infrastructure: Review of current research and identification of future challenges. Int. J. Sustain. Manuf. 2008, 1, 145-167. [CrossRef]

12. Gross, S. End-of-Life Vehicles Management in Europe-Driving the Change; Lund University: Lund, Sweden, 2008.

13. Wegener, K.; Andrew, S.; Raatz, A.; Dröder, K.; Herrmann, C. Disassembly of electric vehicle batteries using the example of the Audi Q5 hybrid system. Procedia CIRP 2014, 23, 155-160. [CrossRef]

14. Aguirre, K.; Eisenhardt, L.; Lim, C.; Nelson, B.; Norring, A.; Slowik, P.; Tu, N. Lifecycle Analysis Comparison of a Battery Electric Vehicle and a Conventional Gasoline Vehicle; California Air Resources Board: Sacramento, CA, USA, 2012; Volume 6, pp. 107-111.

15. Berg, H.; Zackrisson, M. Perspectives on environmental and cost assessment of lithium metal negative electrodes in electric vehicle traction batteries. J. Power Sources 2019, 415, 83-90. [CrossRef]

16. Hall, D.; Lutsey, N. Effects oF Battery Manufacturing on Electric Vehicle Life-Cycle Greenhouse Gas Emissions. Available online: http://www.theicct.org/publications/EV-battery-manufacturing-emissions (accessed on 15 February 2019).

17. Zackrisson, M. Life Cycle Assessment of Long Life Lithium Electrode for Electric Vehicle Batteries: Cells for Leaf, Tesla and Volvo Bus; Swerea IVF: Mölndal, Sweden, 2017; p. 50.

18. Yoney, D. 7 Electric Cars With The Biggest Batteries. Available online: https://insideevs.com/seven-electriccars-biggest-batteries/ (accessed on 15 February 2019).

19. EVDB. Tesla Model S 75D. Available online: https://ev-database.org/car/1070/Tesla-Model-S-75D\#charging (accessed on 14 March 2019).

20. Zackrisson, M. De Vanligaste Litiumjonbatterierna Kemier och Produktionsvolymer 2016 Och Framåt; Swerea IVF: Mölndal, Sweden, 2017.

21. Nitta, N.; Wu, F.; Lee, J.T.; Yushin, G. Li-ion battery materials: Present and future. Mater. Today 2015, 18, 252-264. [CrossRef]

22. Pavel, C.C.; Thiel, C.; Degreif, S.; Blagoeva, D.; Buchert, M.; Schüler, D.; Tzimas, E. Role of substitution in mitigating the supply pressure of rare earths in electric road transport applications. Sustain. Mater. Technol. 2017, 12, 62-72. [CrossRef]

23. Sakti, A.; Michalek, J.J.; Fuchs, E.R.; Whitacre, J.F. A techno-economic analysis and optimization of Li-ion batteries for light-duty passenger vehicle electrification. J. Power Sources 2015, 273, 966-980. [CrossRef] 
24. Rothgang, S.; Baumhöfer, T.; van Hoek, H.; Lange, T.; De Doncker, R.W.; Sauer, D.U. Modular battery design for reliable, flexible and multi-technology energy storage systems. Appl. Energy 2015, 137, 931-937. [CrossRef]

25. Saw, L.H.; Ye, Y.; Tay, A.A. Integration issues of lithium-ion battery into electric vehicles battery pack. J. Clean. Prod. 2016, 113, 1032-1045. [CrossRef]

26. Arora, S.; Shen, W.; Kapoor, A.J.R.; Reviews, S.E. Review of mechanical design and strategic placement technique of a robust battery pack for electric vehicles. Renew. Sustain. Energy Rev. 2016, 60, 1319-1331. [CrossRef]

27. Lindsten, P.-O. Det här är Sveriges 500 största företag 2015 (“These are Swedens 500 largest enterprices" in Swedish). Available online: https://www.va.se/nyheter/2015/12/16/det-har-ar-sveriges-500-storsta-foretag2015/ (accessed on 28 December 2018).

28. SCB. Näringslivets (SNI Sektion A-S exkl K och O) Förädlingsvärde per Region (län) Fördelat på Bransch (SNI Sektioner) 2013, Procent; Statistiska Centralbyrån: Stockholm, Sweden, 2015.

29. FKG. Fordonsindustrin. Available online: http://www.fkg.se/fordonsindustrin/ (accessed on 30 January 2019).

30. Vogel, L.; Vogel, J. Automobile Sector and Competition Law: An Overview of EU and National Case Law. In Competition Law Digest: A Synthesisis of EU and National Leading Cases; Jenny, F., Charbit, N., Eds.; Institute of Competition Law: Paris, France, 2010.

31. EU. Regulation (EC) No 443/2009 of the European Parliament and of the Council of 23 April 2009 setting emission performance standards for new passenger cars as part of the Community's integrated approach to reduce $\mathrm{CO}_{2}$ emissions from light-duty vehicles. Off. J. Eur. Union 2009, 140, 5-6.

32. Ruff, F. The advanced role of corporate foresight in innovation and strategic management-Reflections on practical experiences from the automotive industry. Technol. Forecast. Soc. Chang. 2015, 101, 37-48. [CrossRef]

33. Rohrbeck, R.; Battistella, C.; Huizingh, E. Corporate foresight: An emerging field with a rich tradition. Technol. Forecast. Soc. Chang. 2015, 101, 1-9. [CrossRef]

34. Shahbazi, S.; Sjödin, C.; Bjelkemyr, M.; Wiktorsson, M. A foresight study on future trends influencing material consumption and waste generation in production. In Proceedings of the 24th International Conference on Flexible Automation and Intelligent Manufacturing FAIM2014, San Antonio, TX, USA, 20-23 May 2014.

35. Yılmaz, S.; Ustaoğlu, M. Electric Vehicles Production in Turkish Automotive Industry and Sectoral PEST Analisys. Procedia-Soc. Behav. Sci. 2013, 75, 10-17. [CrossRef]

36. Mehlhart, G.; Hermann, A.; Baron, Y.; Kosińska, I. Assessment of the Implementation of Directive 2000/53/EU on End-of-Life Vehicles (the ELV Directive) with Emphasis on the End of Life Vehicles of Unknown Whereabouts; EU Publications: Luxembourg, Luxembourg, 2018.

37. Huisman, J.; Habib, H.; Brechu, M.G.; Downes, S.; Herreras, L.; Løvik, A.N.; Wäger, P.; Cassard, D.; Tertre, F.; Mählitz, P. ProSUM: Prospecting Secondary raw materials in the Urban mine and Mining wastes. In Proceedings of the Electronics Goes Green 2016+(EGG), Berlin, Germany, 6-9 September 2016; pp. 1-8.

38. Andersson, M. Towards Recycling of Scarce Metals from Complex Products. Ph.D. Thesis, Chalmers University of Technology, Göteborg, Sweden, 2018.

39. Aaltonen, M.; Peng, C.; Wilson, B.P.; Lundström, M. Leaching of Metals from Spent Lithium-Ion Batteries. Recycling 2017, 2, 20. [CrossRef]

40. Wittstock, R.; Pehlken, A.; Wark, M. Challenges in automotive fuel cells recycling. Recycling 2016, 1, 343. [CrossRef]

41. Sakai, S.; Yoshida, H.; Hiratsuka, J.; Vandecasteele, C.; Kohlmeyer, R.; Rotter, V.S.; Passarini, F.; Santini, A.; Peeler, M.; Li, J. An international comparative study of end-of-life vehicle (ELV) recycling systems. J. Mater. Cycles Waste Manag. 2014, 16, 1-20. [CrossRef]

42. Elwert, T.; Goldmann, D.; Römer, F.; Buchert, M.; Merz, C.; Schueler, D.; Sutter, J. Current developments and challenges in the recycling of key components of (hybrid) electric vehicles. Recycling 2016, 1, 25. [CrossRef]

43. EU. Commission Regulation (EU) No 461/2010 of 27 May 2010 on the application of Article 101(3) of the Treaty on the Functioning of the European Union to categories of vertical agreements and concerted practices in the motor vehicle sector. In Document 32010R0461; Commission, E., Ed.; EUR-Lex: Brussels, Belgium, 2010; Volume 461.

44. Jensen, C.; Felix, J.; Söderman, M.L.; Alongi, S.; Skenhall, T.R.; Rapport, B. Utvärdering av Förändrad Demontering och Återvinning av Uttjänta Fordon i Sverige; IVL Swedish Environmental Research Institute: Gothenburg, Sweden, 2012; Volume 2086. 
45. Dalhammar, C.; Machacek, E.; Bundgaard, A.; Zacho, K.O.; Remmen, A. Addressing Resource Efficiency through the Ecodesign Directive: A Review of Opportunities and Barriers; Nordic Council of Ministers: København, Denmark, 2014.

46. Mohan, T.K.; Amit, R. Dismantlers' dilemma in end-of-life vehicle recycling markets: A system dynamics model. Ann. Oper. Res. 2018, 1-29. [CrossRef]

47. Bulach, W.; Schüler, D.; Sellin, G.; Elwert, T.; Schmid, D.; Goldmann, D.; Buchert, M.; Kammer, U. Electric vehicle recycling 2020: Key component power electronics. Waste Manag. Res. 2018, 36, 311-320. [CrossRef]

48. Chen, Z.; Chen, D.; Wang, T.; Hu, S. Policies on end-of-life passenger cars in China: Dynamic modeling and cost-benefit analysis. J. Clean. Prod. 2015, 108, 1140-1148. [CrossRef]

49. Kierkegaard, S.J.C.L.; Review, S. Charging up the batteries: Squeezing more capacity and power into the new EU Battery Directive. Comput. Law Secur. Rev. 2007, 23, 357-364. [CrossRef]

50. Wegener, K.; Chen, W.H.; Dietrich, F.; Dröder, K.; Kara, S. Robot assisted disassembly for the recycling of electric vehicle batteries. Procedia CIRP 2015, 29, 716-721. [CrossRef]

51. Li, J.; Barwood, M.; Rahimifard, S. Robotic disassembly for increased recovery of strategically important materials from electrical vehicles. Robot. Comput. Integr. Manuf. 2018, 50, 203-212. [CrossRef]

52. Sperling, D. Three Revolutions: Steering Automated, Shared, and Electric Vehicles to a Better Future; Island Press: Washington, DC, USA, 2018.

53. NVV. Med de Nya Svenska Klimatmålen i Sikte (With Aim at the New Swedish Climate Goals, in Swedish); Naturvårdsverket (Swedish EPA): Stockholm, Sweden, 2017.

54. Küpper, D.; Kuhlmann, K.; Wolf, S.; Pieper, C.; Xu, G.; Ahmad, J. The Future of Battery Production for Electric Vehicles; Boston Consulting Group: Boston, MA, USA, 2018.

55. Metro. Kolla livslängden på din bil. Available online: https://www.metro.se/artikel/kolla-livsl\%C3\% A4ngden-p\%C3\%A5-din-bil-xr (accessed on 30 January 2019).

56. SCB. Personbilar i Trafik 1923-2017, Tidsserie; SCB/Trafikanalys, Ed.; Statistikmyndigheten SCB (Statistiska Centralbyrån): Stockholm, Sweden, 2018.

57. Schönemann, M.; Bockholt, H.; Thiede, S.; Kwade, A.; Herrmann, C. Multiscale simulation approach for production systems. Int. J. Adv. Manuf. Technol. 2019, 1-18. [CrossRef]

(C) 2019 by the authors. Licensee MDPI, Basel, Switzerland. This article is an open access article distributed under the terms and conditions of the Creative Commons Attribution (CC BY) license (http://creativecommons.org/licenses/by/4.0/). 